\title{
Antibacterial activity of geraniin from sugar maple leaves: an ultrastructural study with the phytopathogen Xanthomonas campestris pv. vitians
}

\author{
Maxime Delisle-Houde ${ }^{1}$ Martine Blais ${ }^{2} \cdot$ Russell J. Tweddell ${ }^{1}$ Danny Rioux ${ }^{2}$
}

Received: 5 August 2020 / Accepted: 29 December 2020 / Published online: 3 February 2021

(c) Società Italiana di Patologia Vegetale (S.I.Pa.V.) 2021

\begin{abstract}
Effect of geraniin extracted from sugar maple (Acer saccharum) leaves on the viability of the phytopathogen Xanthomonas campestris pv. vitians was evaluated with the SYTOX Green nucleic acid stain, penetrating only compromised membranes, and plate counts. In parallel, structural changes of treated bacteria were examined in transmission electron microscopy (TEM). Based on SYTOX Green and plate counts, geraniin at the minimum bactericidal concentration $(3.125 \mathrm{mg} / \mathrm{ml})$ increased mortality after $45 \mathrm{~min}$ by $37 \%$ and $62 \%$, respectively, when compared with controls. According to observations in TEM, geraniin caused morphological alterations of these rod-shaped bacteria, including degradation of their envelopes, as also suggested by the incorporation of SYTOX. These alterations were often accompanied by cytoplasm leakage and the formation of more pronounced whitish areas in the cytoplasm similar to vacuolization. Moreover, multi-membranous and/ or -wall systems were at times formed in the treated bacteria. The presence of some extracellular electron-dense material was frequently noted around the treated bacteria. The matrix surrounding control bacteria tended to disappear after geraniin treatment. This study highlights for the first time the effect of geraniin on bacterial ultrastructure, thus contributing to a better understanding of the mechanism by which this molecule exerts antibacterial activity.
\end{abstract}

Keywords Geraniin · Xanthomonas campestris pv. vitians · Transmission electron microscopy · Bacterial ultrastructure · Acer saccharum

\section{Introduction}

Geraniin is a hydrolysable tannin widespread in the plants of the family Geraniaceae (Okuda et al. 1980) that was reported for the first time in Geranium thunbergii Siebold ex Lindl. \& Paxton (Okuda et al. 1977). Occurrence of geraniin was thereafter observed in at least 71 plant species in 26 genera over 9 different families (Cheng et al. 2017) including Geraniaceae, Anacardiaceae, Elaeocarpaceae, Euphorbiaceae, Erythroxylaceae, Nymphaeceae,

Maxime Delisle-Houde

maxime.delisle-houde.1@ulaval.ca

Danny Rioux

danny.rioux@canada.ca

1 Département de Phytologie, Université Laval, Québec, QC G1V 0A6, Canada

2 Natural Resources Canada, Canadian Forest Service, Laurentian Forestry Centre, QC G1V 4C7 Québec, Canada
Phyllanthaceae, Rosaceae, and Sapindaceae. DelisleHoude et al. (2020) recently reported the presence of geraniin in autumn-shed leaves of sugar maple (Acer saccharum Marsh.).

Geraniin is known to have several bioactive features beneficial for human health (Perera et al. 2015), including antioxidant (Lin et al. 2008; Palanisamy et al. 2011; Chung et al. 2018), anticancer (Okabe et al. 2001; Li et al. 2013; Vassallo et al. 2013), anti-hypertensive (Lin et al. 2008), osteoprotective (Lu et al. 2015), osteogenic (Mo et al. 2019), neuroprotective (Youn and Jun 2013), antidiarrheal (Kan and Taniyama 1992), and antihyperglycemic (Palanisamy et al. 2011) properties.

The compound geraniin was also shown to have antibacterial activity. This geraniin effect was reported against Escherichia coli, Staphylococcus aureus (Adesina et al. 2000; Gohar et al. 2003), Helicobacter pylori (Funatogawa et al. 2004), Pseudomonas aeruginosa (Adesina et al. 2000), Pseudomonas cichorii (DelisleHoude et al. 2020), Pseudomonas fluorescens (Kurihara 
et al. 1993), Ralstonia solanacearum (Ooshiro et al. 2011), Streptomyces scabies (Ushiki et al. 1998), and Xanthomonas campestris pv. vitians (Delisle-Houde et al. 2020).

Although antibacterial activity of geraniin is well documented, the mechanism by which it exerts its antibacterial effect needs to be elucidated. Thus, the objective of our study was to examine the ultrastructural changes that occur in $X$. campestris pv. vitians, the causal agent of bacterial leaf spot of lettuce, after exposure to geraniin to gain better insight into its mechanism of action.

\section{Materials and methods}

\section{Geraniin}

Geraniin (purity of 96\%) was obtained by semi-preparative HPLC according to the study of Delisle-Houde et al. (2020) following extraction from leaves of sugar maple harvested in the last weeks of October, in 2015 and 2016, on the ground next to Roger-Van den Hende botanical garden (46 46'33.6"N 71 17'00.1"W; Québec, QC, Canada). Geraniin was stored into various aliquots at $-85^{\circ} \mathrm{C}$.

\section{Xanthomonas campestris pv. vitians}

The virulent strain B07-007 of $X$. campestris pv. vitians (Agriculture and Agri-Food Canada, Saint-Jean-surRichelieu, QC, Canada), previously used in Delisle-Houde et al. (2020), was tested in the present study. The strain was preserved at $-85^{\circ} \mathrm{C}$ in a glycerol solution $(15 \%, \mathrm{w} / \mathrm{v})$ (VWR International, West Chester, PA, USA). Xanthomonas campestris pv. vitians was cultivated at $28^{\circ} \mathrm{C}$ for $48 \mathrm{~h}$ on tryptic soy agar (TSA, Becton, Dickinson and Company, Sparks, MD, USA). The bacteria were then cultivated in flasks containing $20 \mathrm{ml}$ of TSA and grown under agitation (160 rev/min) for $24 \mathrm{~h}$ at $28^{\circ} \mathrm{C}$. They were recovered by centrifugation $\left(2,360 \times \mathrm{g}, 5 \mathrm{~min}, 22^{\circ} \mathrm{C}\right)$ and suspended in a physiological saline solution $(0.5 \% \mathrm{NaCl}, \mathrm{pH} 7.0)$ to a concentration of $2 \times 10^{9} \mathrm{CFU}$ colony-forming units (CFU)/ $\mathrm{ml}$. Bacterial concentrations were assessed and adjusted by optical density at $600 \mathrm{~nm}\left(\mathrm{OD}_{600 \mathrm{~nm}}\right)$ with $0.5 \mathrm{McFarland}$ standards using a BioMate 3 spectrophotometer (Thermo Electron Corporation, Madison, WI, USA) (Wiegand et al. 2008). Bacterial suspension was added to an equal volume of geraniin solution to obtain a final concentration of $3.125 \mathrm{mg} /$ $\mathrm{ml}$ or in distilled sterile water (control).

\section{SYTOX green nucleic acid stain}

Bacteria were suspended in geraniin and control solutions as previously described and incubated $45 \mathrm{~min}$ at room temperature to obtain a concentration of $1 \times 10^{9} \mathrm{CFU} /$ $\mathrm{ml}$. This suspension was diluted in the physiological solution to $1 \times 10^{8} \mathrm{CFU} / \mathrm{ml}$ and an aliquot was combined with an equal volume of SYTOX Green nucleic acid stain (Molecular Probes, Eugene, Oregon, USA), a compound that penetrates only damaged membranes, in glycerol anti-fade mounting medium containing 2.5\% $\mathrm{Dabco}^{\mathrm{TM}}$ (Sigma-Aldrich Inc., St. Louis, MO, USA) (Johnson et al. 1982) to a final concentration of $10 \mu \mathrm{M}(\mathrm{pH}$ 8.6). After incubating on an orbital shaker (500 rpm) for $5 \mathrm{~min}$ at room temperature in the dark, these mixtures were mounted and examined with a Polyvar light microscope (Reichert, Vienna, Austria) under blue light excitation using a BP 450-490 excitation filter combined with a DS separator mirror 510 and a 515 barrier filter LP. For each treatment, using a hemacytometer (bacteria counted in five squares, each 1 $\mathrm{mm}^{2}$ ), the percentage of fluorescent bacteria was based on those reacting with SYTOX under blue illumination divided by the total number of cells counted immediately thereafter in the same field under normal light. Each treatment was tested in two replicates. The experiment was conducted twice. High-resolution fluorescence and DIC bacterial images were obtained with an inverted IX83 confocal microscope coupled to a Fluoview FV 1200 laser scanning unit (Olympus Corporation, Tokyo, Japan). Excitation for SYTOX Green was provided by an argon ion laser $(488 \mathrm{~nm})$ and fluorescence emission was recorded through a $500-520 \mathrm{~nm}$ band pass filter.

\section{Plate counts}

Plate counts were carried out in parallel to the SYTOX Green nucleic acid stain test. After a serial dilution, $100 \mu \mathrm{l}$ of the bacterial suspensions $\left(1 \times 10^{8} \mathrm{CFU} / \mathrm{ml}\right)$ were spread on TSA Petri plates and incubated at $28^{\circ} \mathrm{C}$ for $48 \mathrm{~h}$. The number of viable bacteria was determined only with Petri dishes showing a range of 30-300 colonies. Each treatment was tested in two replicates (three samples per replicate). The experiment was conducted twice.

\section{Statistical analysis}

For both SYTOX and plant counts, mortality rate of geraniin treated cells was compared to that of control cells using t-test in $\mathrm{R}$ version 3.4.3 (R Core Team 2017). 


\section{Bacterial ultrastructure}

Processing for TEM was mainly carried out with a PELCO Microwave Pro oven (PELCO international, Redding, CA). To minimize the effect of centrifugation on bacterial ultrastructure, $200 \mu \mathrm{l}$ of $15 \%$ glutaraldehyde $(\mathrm{pH}$ 7.0, Canemco Inc., Montreal, Quebec, Canada) in $0.1 \mathrm{M}$ sodium cacodylate buffer (SCB, pH 7.0, Canemco Inc.) were added to each tube and processed under controlled microwave conditions: $0 \mathrm{~W}$ (15 min) under vacuum (15 in of $\mathrm{Hg}$ ) with a restrictive temperature set to $26^{\circ} \mathrm{C}$. This primary fixation was followed by an additional $15 \mathrm{~min}$ in the same solution at room temperature. Cells were centrifuged (Eppendorf ${ }^{\circledR}$ Microcentrifuge Model 5415R) at $5000 \mathrm{rpm}$ for $5 \mathrm{~min}$ at $4{ }^{\circ} \mathrm{C}$. The recovered pellet was fixed with $3 \%$ glutaraldehyde, $0.2 \%$ ruthenium red, and $\mathrm{CaCl}_{2}(0.05 \mathrm{M})$ in $0.1 \mathrm{M} \mathrm{SCB}$. We used ruthenium red in a previous ultrastructural study on bacteria (Yaganza et al. 2004), this stain being particularly useful in TEM to highlight the matrix often present around bacteria (Fletcher 1990). The bacteria were then embedded in 30 $\mu \mathrm{l}$ of the following solution: $18 \mu \mathrm{l}$ of $25 \%$ glutaraldehyde plus $42 \mu \mathrm{l}$ of bovine serum albumin (BSA) to obtain a final concentration of $5 \%$ glutaraldehyde. After polymerization, bacteria included in gels $\left(\sim 2-3 \mathrm{~mm}^{3}\right)$ were fixed with this microwave setting: $150 \mathrm{~W}(1 \mathrm{~min})$, $0 \mathrm{~W}$ (1 min), $150 \mathrm{~W}$ (1 min) under vacuum (15 in of $\mathrm{Hg}$ ). Rinsing, postfixation with $\mathrm{OsO}_{4}$, ethanol dehydration, propylene oxide dehydration and contrasting before observations with TEM were conducted as described in Rioux et al. (2018) except the resin infiltration with Poly/ Bed 812 epoxy (Polysciences, Warrington, PA) that was carried out with the following setting: $300 \mathrm{~W}(8 \mathrm{~min})$, $300 \mathrm{~W}$ (1 min), $300 \mathrm{~W}$ (3 min) and $200 \mathrm{~W}(3 \mathrm{~min})$ under vacuum at 15 inches of $\mathrm{Hg}$ (the vacuum was used just for the last step). After polymerization for $48 \mathrm{~h}$ at $60^{\circ} \mathrm{C}$, ultrathin sections $(\sim 90 \mathrm{~nm})$ were examined with a JEM1230 (JEOL, Peabody, MA, USA) transmission electron microscope operating at $80 \mathrm{kV}$. The experiment was conducted twice.

\section{Results}

\section{Effect of geraniin on the viability of $X$. campestris pv. vitians}

SYTOX Green fluorescent cells are shown in Fig. 1; these cells were considered dead. Based on the number of fluorescent cells, mortality rate of bacteria treated (45 min) with geraniin $(3.125 \mathrm{mg} / \mathrm{ml})(50 \%)$ was significantly $(p<0.05)$ higher than the mortality rate of control cells (13\%) (Table 1).
According to plate counts, mortality rate of bacteria treated with geraniin $(87 \%)$ was also significantly $(p<0.01)$ higher than the mortality rate of control cells $(25 \%)$. Bacteria in division or those that have just divided were more common in controls (Fig. 1a) than in treated cells (Fig. 1c).

\section{Ultrastructure of control (untreated) bacteria}

The vast majority of control bacterial cells displayed a structure in TEM comparable with that of other gramnegative bacteria. Ribosomes were obvious and numerous (Fig. 2) and at times they were accompanied by large dark inclusions (Fig. 2a). Nucleoids were also evident, corresponding to regions of poor electron-opacity. At low magnification, the cell envelope appears composed of two dense layers separated by an electron-translucent band, but at times at higher magnification, other layers were also distinguishable (Fig. 2b), notably two white lines corresponding to the periplasm space enclosing a denser layer that is composed of peptidoglycans. An outer membrane and an internal membrane surrounded this region. Vesicles were visible at times, attached to the outer membrane (Fig. 2a, b), especially in areas where the plane of sectioning seemed to go diagonal to the cell envelope (Fig. 2c). Finally, cellular divisions were frequently observed among these bacteria (Fig. 2a) and all the control cells were surrounded by a granular grey matrix (Fig. 2).

\section{Ultrastructural changes in bacteria after geraniin treatment}

After geraniin treatment, some bacteria showed irregular or deformed shapes (Fig. 3a). High-density material was only noticeable close to bacteria and in some cases, it was even seen embedded within cell envelopes (Fig. 3a-c). While some of the matrix was still recognizable at times (Fig. 3a, b), it tended to disappear in most areas (Fig. 3cf). Structures that look like cell envelope debris (Fig. 3a-d) and cytoplasm leakage mixed with electron-opaque material were common, especially when bacteria presented altered envelopes (Fig. 3a, d). At times, the envelopes were hardly recognizable around these cells and then the electron-opaque material was prominently associated with these bacteria (Fig. 3e, f). The extracellular electron-dense material was sometimes seen surrounding more translucent substances (Fig. 3b-e). In some cases, it was possible to see whitish areas comparable to cytoplasmic vacuolization (Fig. 3e), and/or at times possible slight DNA condensation in nucleoid zones (Fig. 3f). Multi-membranous and/or -wall systems were also formed within bacteria (Fig. 3c), more frequently near the small ends of these cells (Fig. 3b). The outer membrane vesicles described in the previous section 

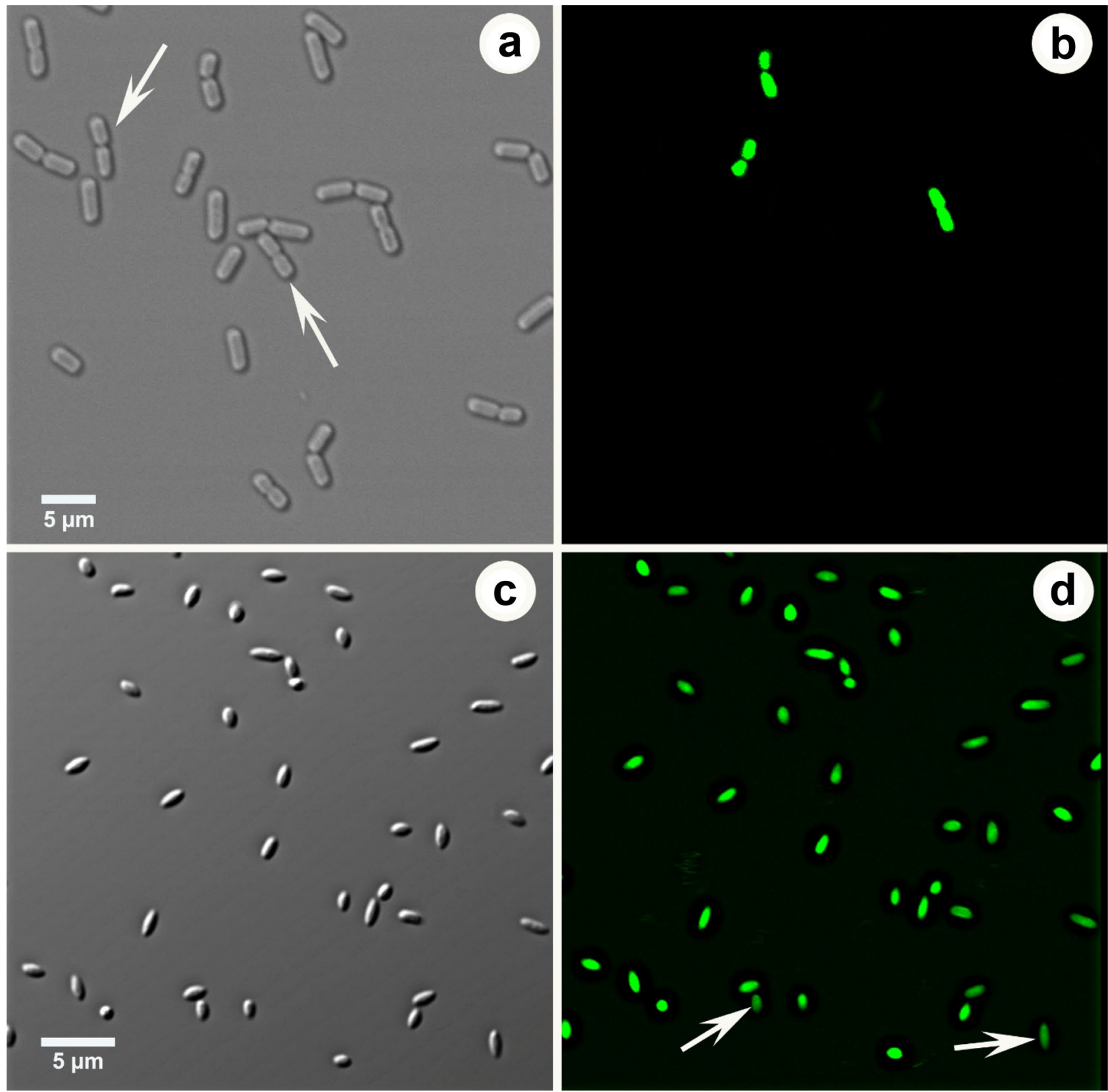

Fig. 1 Xanthomonas campestris pv. vitians observed in confocal microscopy using SYTOX Green. a-b. Same field of untreated bacteria (control) observed in differential interference contrast a and in fluorescence b. Some bacteria in division or those that have just divided

are clearly fluorescent while others are not (arrows). c-d. Same field of bacteria treated with geraniin examined in differential interference contrast $\mathbf{c}$ and in fluorescence $\mathbf{d}$. All cells react with SYTOX although some (arrows) are less fluorescent than others

appeared at times even more easily distinguishable when bacteria were grown in presence of geraniin than in control bacteria (Fig. 3e, f), and then they were occasionally closely associated with electron-opaque extraneous material (Fig. 3f). The dark inclusions in the cytoplasm were still regularly visible in treated cells (Fig. 3a-c, e, f).

\section{Discussion}

This study showed that geraniin has a bactericidal effect on X. campestris pv. vitians and explained a part of its mode of action by examining its impacts in microscopy, particularly at the ultrastructural level. Incorporation of 
Table 1 Evaluation of the effect of geraniin on bacterial viability using SYTOX Green and plate counts

\begin{tabular}{lllll}
\hline Treatment & Total cells (CFU/ml) & Live cells (CFU/ml) & Dead cells (CFU/ml) & Mortality (\%) \\
\hline $\begin{array}{llll}\text { SYTOX Green } \\
\text { Geraniin }^{\mathrm{a}}\end{array}$ & $1.44 \times 10^{7}$ & $7.20 \times 10^{6}$ & $7.20 \times 10^{6}$ & $50^{*}$ \\
Control & $1.73 \times 10^{7}$ & $1.51 \times 10^{7}$ & $2.22 \times 10^{6}$ & $13^{*}$ \\
Plate counts & & & \\
Geraniin $^{\mathrm{a}}$ & $1 \times 10^{8}$ & $1.30 \times 10^{7}$ & $8.70 \times 10^{7 \mathrm{~b}}$ & $87^{* *}$ \\
Control & $1 \times 10^{8}$ & $7.50 \times 10^{7}$ & $2.50 \times 10^{7 \mathrm{~b}}$ & $25^{* *}$ \\
\hline
\end{tabular}

Each value represents the mean of two experiments, each of two replicates

* Means significantly different $(p<0.05)$ according to t-test

** Means significantly different $(p<0.01)$ according to t-test

${ }^{\text {a }}$ Cells were exposed to geraniin $(3.125 \mathrm{mg} / \mathrm{ml})$ for $45 \mathrm{~min}$

${ }^{\mathrm{b}}$ Dead cells for plate counts were determined by subtracting living cells from total cells
SYTOX Green nucleic acid stain and plate counts showed that geraniin treatment (45 $\mathrm{min})$, even at the minimum bactericidal concentration $(3.125 \mathrm{mg} / \mathrm{ml})$ as determined by Delisle-Houde et al. (2020), caused a clear increase of
$X$. campestris pv. vitians mortality when compared with controls. SYTOX Green is used for assessing cell viability through verifying the integrity of the plasma membrane. Bacteria were the first cells tested with SYTOX Green where
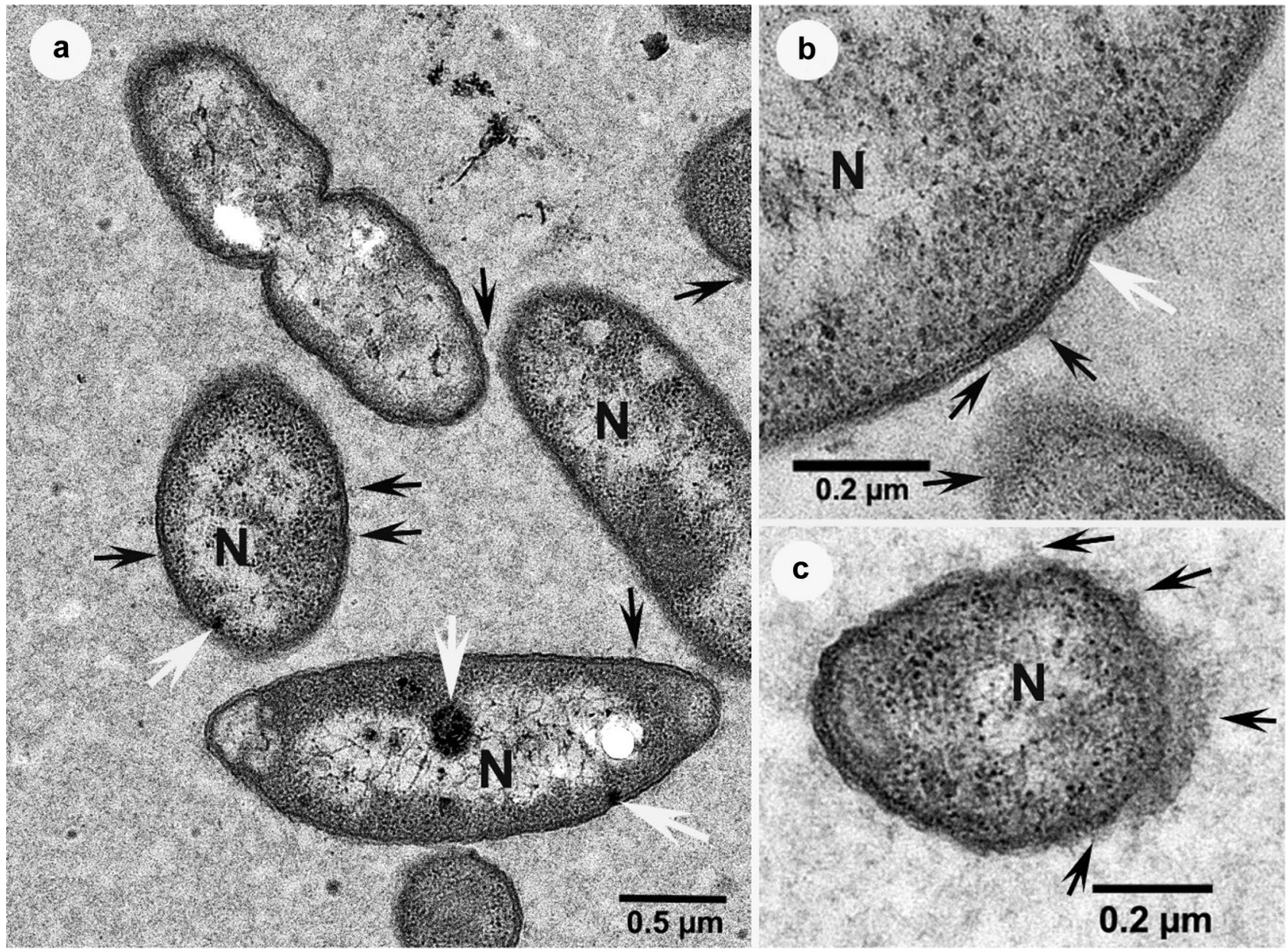

Fig. 2 Transmission electron micrographs of non-treated (control) bacterial cells, surrounded by a granular grey matrix, showing ribosomes, vesicles (black arrows) and nucleoids $(\mathrm{N})$. a The bacterium at the top of the figure is clearly in the process of binary fission and large dark inclusions are also visible within some bacteria (white arrows). b Several electron-opaque and translucent layers are distinguishable at high magnification, in particular two obvious white layers in the centre of the wall in an area (white arrow). c Areas rich in vesicles where the plane of sectioning seemed to go diagonal to the cell envelope 


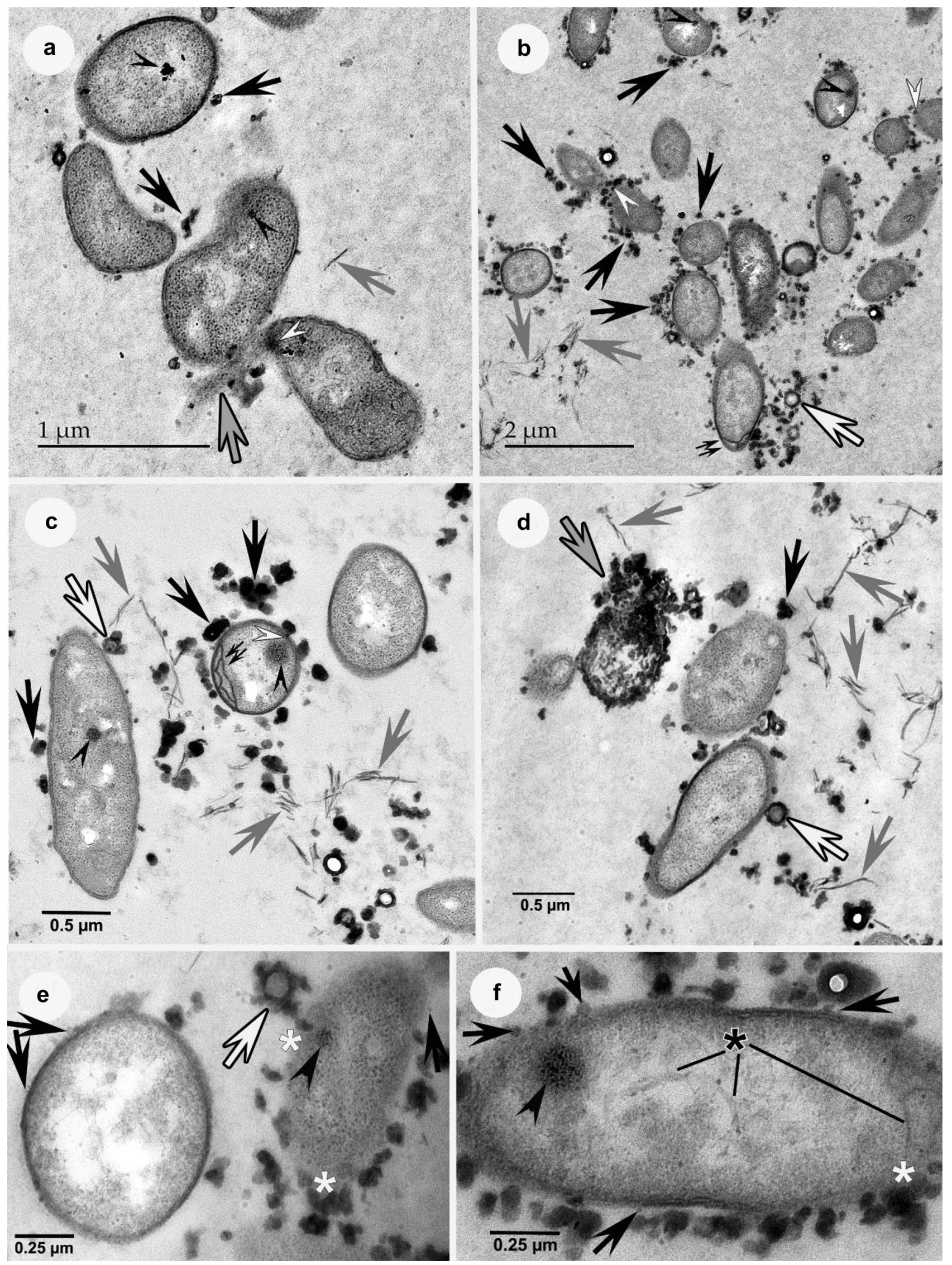


4Fig. 3 Transmission electron micrographs of bacterial cells treated with geraniin where the grey matrix encompassing bacteria are less obvious (particularly c-f) than in controls (Fig. 2). Gray arrows = wall debris; black \& white arrows=electron-opaque material with a translucent core; black arrowheads $=$ dark inclusions. a-d. Black arrows $=$ electron opaque material. a-c. White arrowheads $=$ electronopaque material within the bacterial envelope. a The three bacteria at the bottom show irregular or deformed shapes. Cytoplasm leakage is obvious (gray \& black arrow) and some electron-opaque material is embedded within the envelope. b-c. High-density material close to bacteria and/or embedded within the envelopes, as well as debris, are clearly distinguishable. Multi-layered walls are visible (doublearrows), especially at the small end of a bacterium in b. d A greatly altered bacterium shows cytoplasm leakage intermixed with electron-opaque matter (gray \& black arrow). e-f. Extracellular electronopaque material abundant, and at times closely associated with vesicles (black arrows), particularly in $\mathbf{f}$. The structure of the envelope is hardly visible, especially the cell on the right in $\mathbf{e}$, where electronopaque matter is abundant, and in some areas appears included within the wall (white asterisks). Cytoplasmic vacuolization appears intense in the left-hand cell in e and in $\mathbf{f}$ DNA condensation seems discernible in the nucleoid (black asterisk)

this fluorochrome provided better results in flow cytometry than LIVE stain, both with gram-positive and gram-negative species (Langsrud and Sundheim 1996), indicating that their membranes were affected after exposure to the disinfectant quaternary ammonium compound. Still with bacteria, Roth et al. (1997) studied their susceptibility to antibiotics and they have reported among other things the first observations of SYTOX Green fluorescence in microscopy. Our results indicated that geraniin causes membrane damage and TEM examination confirmed this result by revealing alteration of bacterial cells, notably their envelope that consists of the plasma membrane and the cell wall, the latter composed of the outer membrane, the peptidoglycan layer and the periplasm (Beveridge 1999). Plate counts are generally used in similar studies because they are more likely to express more precisely the real number of live and dead cells than the evaluation obtained with any fluorochrome. However, it may occasionally happen that two cells instead of one give a single colony, which would result in an overestimation of the mortality rate. The higher mortality rate obtained with plate counts in comparison with SYTOX in our study, either between control or treated cells (Table 1), could be explained by the fact that the latter at times underestimates the number of dead cells (Lebaron et al. 1998). Even though most of the fluorescing bacteria were easy to count (Fig. 1), Lebaron et al. reported some background issues, in particular at times difficulty differentiating the slight fluorescing cells from the non-fluorescent ones. As also noted in their study, as alteration of DNA is likely to occur with time after treatment, for instance just a change of the coiling structure of DNA, the fluorochrome may then likely fail to bind to all the dead cells, even if it had penetrated the compromised membranes.
It is also possible that geraniin affects $X$. campestris pv. vitians without necessarily always altering cell wall and plasma membrane integrity, especially soon after treatment. Yaganza et al. (2004) observed this response with sodium metabisulfite against the gram-negative phytopathogen bacterium Pectobacterium atrosepticum (synonyme: Erwinia carotovora subsp. atroseptica). Cell envelope organization of gram-negative bacteria is instrumental in maintaining cellular soundness, notably their shape (Huang et al. 2008), for instance preventing cell lysis (Cabeen and Jacobs-Wagner 2005; Yount and Yeaman 2013). Moreover, plate counts occasionally could also underestimate the number of viable cells. For instance, Rathnayaka and Rakshit (2009) compared different methods to determine the number of viable Salmonella cells including counts with a hemocytometer with three specific agar media (Rambach agar, Rainbow agar salmonella, and XLT4 agar) and fluorescent in situ hybridization method. Their results with plate counts for each agar medium tested showed a significantly lower quantity of live bacteria in comparison with the expected calculated number using fluorescence and the hemocytometer at the start of the assay.

Antimicrobial activities of tannins, a class of polyphenolic compounds, often termed condensed and hydrolysable tannins, against many microorganisms including filamentous fungi, yeasts, and bacteria, have been oftentimes mentioned in the scientific literature (Scalbert 1991). It is particularly well known that woods more resistant to decay fungi, particularly those from broadleaf species, are frequently rich in tannins (Scalbert 1992).

Bacteriostatic or bactericidal activities of tannins were also clearly shown against some species, including Campylobacter jejuni (Anderson et al. 2012), H. pylori (Funatogawa et al. 2004), E. coli and S. aureus (Nagayama et al. 2002). The effect of tannins, both condensed and hydrolysable ones, on bacterial ultrastructure has also been investigated and many studies described some cellular alterations similar to those observed in the present work. For instance, treated cells presented abnormal shapes (Reverón et al. 2013; Trentin et al. 2013; Xu et al. 2017; Ma et al. 2020), altered (Reverón et al. 2013) and even disrupted envelopes (Trentin et al. 2013), that produced cell leakage and/or release of various debris (Reverón et al. 2013; Trentin et al. 2013), and finally at times intense cytoplasmic vacuolization (Trentin et al. 2013). In Bae et al. (1993), such leakage and accumulation of structural debris were obvious in TEM, but not described in their results, and damage to the outer membrane of the gram-negative Fibrobacter succinogenes was reported, while actually their micrographs rather show that the entire envelopes were degraded following treatment with tannins. 
In the present study, geraniin treatment resulted in the intense accumulation of electron-dense material next to bacteria. Such material was also clearly described around different species of bacteria treated with condensed tannins (Jones et al. 1994). After treatment of S. aureus with the ellagitannin punicalagin (Xu et al. 2017), the authors insisted that bacteria presented a rough surface, which was conspicuous from their TEM micrographs when compared with controls, but they should have added that at least some of this obvious electron-dense wavy surface might be composed by some of the ellagitannin bound to the envelope, because this was more prominent with the highest concentration of punicilagin used in their study compared with half this amount. In Reverón et al. (2013), most of the electron-dense material associated closely or not to the bacterial envelope was described as debris arising from cell leakage while in fact it is most likely that at least some of this material was the tannic acid used in their study that was clearly osmiophilic and/or stained with ruthenium. In Bae et al. (1993), they postulated that this extracellular material was attached to tannins and formed tanninprotein and/or tannin-carbohydrate complexes. Tannic acid appeared indeed to bind to fibrillar proteins (Simionescu and Simionescu 1976; Hayat 2000) and this increases the likelihood that it was present in diverse entities, and/or had provided better preservation of their structures. Thus in our study, all the electron-opaque material blatantly observed around bacteria after geraniin treatment could be constituted in part of some proteinaceous substances.

In another study (Lucas et al. 2012), alterations of Xanthomonas vesicatoria cells, the causal agent of bacterial spot in tomato, were reported after treatment with various essential oils, and several of these ultrastructural changes were similar to ours, such as cytoplasmic vacuolization at times associated with leakage of some electron-dense material. However, their micrographs did not display any accumulation of electron-dense material around bacteria, similar to that just previously discussed, so presumably these oils did not contain any significant amounts of tannin-like components.

It is interesting to note that tannic acid used as in-block staining, also called mordanting reaction, has been reported to improve cell contrast in TEM (Simionescu and Simionescu 1976; Hayat 2000). Although we did not see a striking improvement in the ultrastructural contrast of bacteria after using the tannin geraniin, we suspect that this compound may have prevented lipid extraction to some extent and thus better preserved the integrity of the outer membrane vesicles described in our study. Likewise, tea extracts, of a polyphenolic nature quite similar to that of tannic acid, have even been used as a dense-electronic solution in replacement of uranyl acetate in an ultrastructural study, and as generally reported for the latter compound and tannic acid during TEM examination of plant cells (e.g., Roland and Vian 1991), excellent results were obtained in conjunction with microwave processing, as in the present work, to highlight the fine details of the membranous system of Arabidopsis cells (Carpentier et al. 2012). Thus, geraniin may have improved the preservation of the vesicles observed around $X$. campestris pv. vitians cells but it is also possible that their greater number after treatment than in controls be a reaction to counter the toxicity of this compound. To support this possibility, in the review by Beveridge (1999) on the vesicles produced by gram-negative bacteria, he clearly stressed that one of the postulated roles of such structures may be to deliver enzymes involved in degradation of antibiotics. The physiology of membrane vesicles releasing as a reaction of gram-negative bacteria to various stressors has recently been reviewed (Volgers et al. 2018).

Bacteria treated with geraniin seemed to present a matrix less abundant than in control cells (for instance compare the control in Fig. 2a with Fig. 3c). One of the major findings in Trentin et al. (2013) was that bark extracts, from trees used for medicinal purposes in Brazil, were rich in tannins and impaired the adhesion and biofilm formation of P. aeruginosa, a pathogen that causes nosocomial pneumonia worldwide (e.g., Rossi 2011). The biofilm in question resembles what we have described as a matrix around $X$. campestris $\mathrm{pv}$. vitians cells. As geraniin seriously impacted the integrity of $X$. campestris pv. vitians envelopes, and appeared to degrade the matrix around these cells, it is most likely that this would also reduce its potential to bind to various surfaces, even though this parameter was not evaluated in the current study. Xanthan is an exopolysaccharide naturally produced by several Xanthomonas species, for instance $X$. campestris (Rosalam and England 2006) and $X$. axonopodis (Boher et al. 1997), which was recognized in the latter investigation as being implicated in the adhesion of bacteria with host cells. The use of a monoclonal antibody clearly disclosed the presence of xanthan in bacterial envelopes, in the extracellular matrix and over plant host walls (Boher et al. 1997). Xanthan was also reported as an important component of biofilms produced by $X$. campestris and this matrix would play a key role in bacterial adhesion to plant cells and cell-cell signalling (Dow et al. 2003). Mutants of $X$. campestris defective in the production of xanthan have also been reported as less virulent in plants than their parental strains (Katzen et al. 1998). This suggests that geraniin could not only affect the viability of $X$. campestris pv. vitians but also its virulence. Secretion of various substances by gramnegative bacteria and their importance in adhesion and virulence have been abundantly studied (e.g., Costa et al. 2015; Hews et al. 2019).

To characterize the matrix around $X$. campestris $\mathrm{pv}$. vitians cells, we have tried to purchase monoclonal antibodies that were used in the past, for example by Boher et al. (1997), but 
we realized that all the permits to grow hybridomas, made by the fusion of myeloma and antibody-producing cells, have long since expired and no demands for renewing them existed. We have instead used an anti-acetylated mannan as a primary antibody, a mouse IgMk monoclonal antibody described as reacting with tomato gums, and secondary goat anti-mouse IgM conjugated to colloidal gold $(10 \mathrm{~nm})$ but unfortunately we estimated that the labelling was not consistent enough to draw any solid conclusions about the chemical nature of the matrix (unpublished results).

Bacteria and viruses are the most lethal and infectious pathogens of humans, having caused several pandemic diseases, not the least cholera and the current COVID19 , respectively. In phytopathology, the most devastating diseases are caused by far by fungi or fungal-like oomycetes, for instance the infamous Dutch elm disease and potato late blight, respectively. Understandably, the resources and funding to tackle human diseases are immense when compared with those devoted to phytopathology. Thus, we are often dependent upon the technology developed in the medical field to help us understand and control plant diseases. In recent years, gram-negative bacteria affecting humans have been studied in microscopy using mainly new cryo-technologies such as electron cryotomography to better understand their fine structure, for instance the nature of the periplasm within the envelope (Oikonomou and Jensen 2017). In the present study, conventional chemical fixation with reagents such as glutaraldehyde and $\mathrm{OsO}_{4}$ were used together with a microwave oven to improve their penetration rate and reduce the processing time. As this sample processing was successfully used in other studies (e.g., Laue et al. 2007; Carpentier et al. 2012), the ultrastructural preservation of $X$. campestris pv. vitians cells surely also met a high standard of quality, allowing us to conclude that geraniin impacted the viability of this phytopathogen through modifying its ultrastructure, notably the wall and its plasma membrane. As reported in the thorough review by Cheng et al. (2017), the mechanisms by which this much studied molecule exerts beneficial human health effects, notably through antimicrobial activities, needs to be further elucided, and taken altogether the results of our study clarify, at least in part, the mode of action of this molecule and might thus explain the mechanism by which bacterial leaf spot severity of lettuce was significantly reduced when plants were vaporised with plant extracts (Delisle-Houde and Tweddell 2020) that were shown to contain noticeable concentrations of the potent geraniin (Delisle-Houde et al. 2020).

Acknowledgements We gratefully acknowledge Vicky Toussaint, Agriculture and Agri-Food Canada, for having graciously provided the bacterial strain and Ministère de l'Agriculture, des Pêcheries et de l'Alimentation du Québec for financial support.

\section{References}

Adesina SK, Idowu O, Ogundaini AO, Oladimeji H, Olugbade TA, Onawunmi GO, Pais M (2000) Antimicrobial constituents of the leaves of Acalypha wilkesiana and Acalypha hispida. Phytother Res 14:371-374. https://doi.org/10.1002/10991573(200008) 14:5\%3c371::AID-PTR625\%3e3.0.CO;2-F

Anderson RC, Vodovnik M, Min BR, Pinchak WE, Krueger NA, Harvey RB, Nisbet DJ (2012) Bactericidal effect of hydrolysable and condensed tannin extracts on Campylobacter jejuni in vitro. Folia Microbiol 57:253-258. https://doi.org/10.1007/s12223-012-0119-4

Bae HD, McAllister TA, Yanke J, Cheng K-J, Muir AD (1993) Effects of condensed tannins on endoglucanase activity and filter paper digestion by Fibrobacter succinogenes S85. Appl Environ Microbiol 59:2132-2138

Beveridge TJ (1999) Structures of Gram-negative cell walls and their derived membrane vesicles. J Bacteriol 181:4725-4733. https:// doi.org/10.1128/JB.181.16.4725-4733.1999

Boher B, Nicole M, Potin M, Geiger JP (1997) Extracellular polysaccharides from Xanthomonas axonopodis pv. manihotis interact with cassava cell walls during pathogenesis. MPMI 10:803-811. https://doi.org/10.1094/MPMI.1997.10.7.803

Cabeen MT, Jacobs-Wagner C (2005) Bacterial cell shape. Nat Rev Microbiol 3:601-610. https://doi.org/10.1038/nrmicro1205

Carpentier A, Abreu S, Trichet M, Satiat-Jeunemaitre B (2012) Microwaves and tea: new tools to process plant tissue for transmission electron microscopy. J Microsc 247:94-105. https:// doi.org/10.1111/j.1365-2818.2012.03626.x

Cheng HS, Ton SH, Kadir KA (2017) Ellagitannin geraniin: a review of the natural sources, biosynthesis, pharmacokinetics and biological effects. Phytochem Rev 16:159-193. https://doi.org/10.1007/ s11101-016-9464-2

Chung APYS, Gurtu S, Chakravarthi S, Moorthy M, Palanisamy UD (2018) Geraniin protects high-fat diet-induced oxidative stress in Sprague Dawlay rats. Front Nutr 5:17. https://doi.org/10.3389/ fnut.2018.00017

Costa TRD, Felisberto-Rodrigues C, Meir A, Prevost MS, Redzej A, Trokter M, Waksman G (2015) Secretion systems in Gramnegative bacteria: structural and mechanistic insights. Nature Rev Microbiol 13:343-359. https://doi.org/10.1038/nrmicro3456

Delisle-Houde M, Tweddell RJ (2020) Sugar maple autumn-shed leaf extract: a potential antibacterial agent for the management of lettuce bacterial leaf spot (Xanthomonas campestris pv. vitians) and varnish spot (Pseudomonas cichorii). Can J Plant Sci 100:7885. https://doi.org/10.1139/cjps-2019-0040

Delisle-Houde M, Dubé P, Tweddell RJ (2020) Antibacterial activity of sugar maple autumn-shed leaf extract: identification of the active compound. Ann Appl Biol 177:51-60. https://doi.org/10.1111/ aab. 12598

Dow JM, Crossman L, Findlay K, He YQ, Feng JX, Tang JL (2003) Biofilm dispersal in Xanthomonas campestris is controlled by cellcell signaling and is required for full virulence to plants. PNAS 100:10995-11000. https://doi.org/10.1073/pnas.1833360100

Fletcher M (1990) Methods for studying adhesion and attachment to surfaces. In: Grigorova R, Norris JR (eds) Method Microbiol, Academic Press Ltd, London, UK, pp 251-283. https://doi. org/10.1016/S0580-9517(08)70245-9

Funatogawa K, Hayashi S, Shimomura H, Yoshida T, Hatano T, Ito H, Hirai Y (2004) Antibacterial activity of hydrolyzable tannins derived from medicinal plants against Helicobacter pylori. Microbiol Immunol 48:251-261. https://doi. org/10.1111/j.1348-0421.2004.tb03521.x

Gohar AA, Lahloub MF, Niwa M (2003) Antibacterial polyphenol from Erodium glaucophyllum. Z Naturforsch C 58:670-674. https://doi.org/10.1515/znc-2003-9-1013 
Hayat MA (2000) Principles and techniques of electron microscopy - Biological Applications, 4th edn, Cambridge University Press, London, UK.

Hews CL, Cho T, Rowley G, Raivio TL (2019) Maintaining integrity under stress: envelope stress response regulation of pathogenesis in gram-negative bacteria. Front Cell Infect Microbiol 9:313. https://doi.org/10.3389/fcimb.2019.00313

Huang KC, Mukhopadhyay R, Wen B, Gitai Z, Wingreen NS (2008) Cell shape and cell-wall organization in Gram-negative bacteria. PNAS 105:19282-19287. https://doi.org/10.1073/ pnas.0805309105

Johnson GD, Davidson RS, McNamee KC, Russell G, Goodwin D, Holborow EJ (1982) Fading of immunofluorescence during microscopy: a study of the phenomenon and its remedy. J Immunol Methods 55:231-242. https://doi.org/10.1016/00221759(82)90035-7

Jones GA, McAllister TA, Muir AD, Cheng K-J (1994) Effects of sainfoin (Onobrychis viciifolia Scop.) condensed tannins on growth and proteolysis by four strains of ruminal bacteria. Appl Environ Microbiol 60:1374-1378

Kan S, Taniyama K (1992) Mechanism of inhibitory actions of Geranium thunbergii, tannic acid and geraniin on the motility of rat intestine. Shoyakugaku Zasshi 46:246-253

Katzen F, Ferreiro DU, Oddo CG, Ielmini MV, Becker A, Pühler A, Ielpi L (1998) Xanthomonas campestris pv. campestris gum mutants: effects on xanthan biosynthesis and plant virulence. J Bacteriol 180:1607-1617. https://doi. org/10.1128/JB.180.7.1607-1617.1998

Kurihara H, Kawabata J, Hatano M (1993) Geraniin, a hydrolysable tannin from Nymphaea tetragona Georgi (Nymphaeaceae). Biosci Biotech Biochem 57:1570-1571. https://doi.org/10.1271/ bbb. 57.1570

Langsrud S, Sundheim G (1996) Flow cytometry for rapid assessment of viability after exposure to a quaternary ammonium compound. J Appl Bacteriol 81:411-418. https:// doi.org/10.1111/j.1365-2672.1996.tb03527.x

Laue M, Niederwöhrmeier B, Bannert N (2007) Rapid diagnostic thin section electron microscopy of bacterial endospores. J Microbiol Methods 70:45-54. https://doi.org/10.1016/j. mimet.2007.03.006

Lebaron P, Catala P, Parthuisot N (1998) Effectiveness of SYTOX green stain for bacterial viability assessment. Appl Environ Microbiol 64:2697-2700. https://doi.org/10.1128/ AEM.64.7.2697-2700.1998

Li J, Wang S, Yin J, Pan L (2013) Geraniin induces apoptotic cell death in human lung adenocarcinoma A549 cells in vitro and in vivo. Can J Physiol Pharmacol 91:1016-1024. https://doi. org/10.1139/cjpp-2013-0140

Lin SY, Wang CC, Lu YL, Wu WC, Hou WC (2008) Antioxidant, anti-semicarbazide-sensitive amine oxidase, and anti-hypertensive activities of geraniin isolated from Phyllanthus urinaria. Food Chem Toxicol 46:2485-2492. https://doi.org/10.1016/j. fct.2008.04.007

Lu Y, He B, Zhang X, Yang R, Li S, Song B, Zhang Y, Yun Y, Yan H, Chen P, Shen Z (2015) Osteoprotective effect of geraniin against ovariectomy-induced bone loss in rats. Bioorg Med Chem Lett 25:673-679. https://doi.org/10.1016/j.bmcl.2014.11.081

Lucas GC, Alves E, Pereira RB, Perina FJ, de Souza RM (2012) Antibacterial activity of essential oils on Xanthomonas vesicatoria and control of bacterial spot in tomato. Pesq Agropec Bras 47:351-359. https://doi.org/10.1590/S0100204X2012000300006

Ma Y, Wang Y, Zhang H, Sun W, Li Z, Zhang F, Zhang H, Chen F, Zhang H, An J, He C (2020) Antimicrobial mechanism of strictinin isomers extracted from the root of Rosa roxburghii
Tratt (Ci Li Gen). J Ethnopharmacol 250:112498. https://doi. org/10.1016/j.jep.2019.112498

Mo J, Yang R, Li F, He B, Zhang X, Zhao Y, Shen Z, Chen P (2019) Geraniin promotes osteogenic differentiation of bone marrow mesenchymal stem cells (BMSCs) via activating $\beta$-catenin: a comparative study between BMSCs from normal and osteoporotic rats. J Nat Med 73:262-272. https://doi.org/10.1007/ s11418-018-1242-6

Nagayama K, Iwamura Y, Shibata T, Hirayama I, Nakamura T (2002) Bactericidal activity of phlorotannins from the brown alga Ecklonia kurome. J Antimicrob Chemother 50:889-893. https://doi. org/10.1093/jac/dkf222

Oikonomou CM, Jensen GJ (2017) Cellular electron cryotomography: toward structural biology in situ. Annu Rev Biochem 86:873-896. https://doi.org/10.1146/annurev-biochem-061516-044741

Okabe S, Suganuma M, Imayoshi Y, Taniguchi S, Yoshida T, Fujiki H (2001) New TNF- $\alpha$ releasing inhibitors, geraniin and corilagin, in leaves of Acer nikoense, Megusurino-ki. Biol Pharm Bull 24:1145-1148. https://doi.org/10.1248/bpb.24.1145

Okuda T, Yoshida T, Nayeshiro H (1977) Constituents of Geranium thunbergii Sieb. et Zucc. IV. Ellagitannins. (2). Structure of geraniin Chem Pharm Bull 25:1862-1969. https://doi. org/10.1248/cpb.25.1862

Okuda T, Mori K, Hatano T (1980) The distribution of geraniin and mallotusinic acid in the order Geraniales. Phytochemistry 19:547-551. https://doi.org/10.1016/0031-9422(80)87012-9

Ooshiro A, Kaji M, Katoh Y, Kawaide H, Natsume M (2011) Antibacterial activity of alkyl gallates and related compounds against Ralstonia solanacearum. J Pestic Sci 36:240-242. https:// doi.org/10.1584/jpestics.G10-84

Palanisamy UD, Ling LT, Manaharan T, Appleton D (2011) Rapid isolation of geraniin from Nephelium lappaceum rind waste and its anti-hyperglycemic activity. Food Chem 127:21-27. https:// doi.org/10.1016/j.foodchem.2010.12.070

Perera A, Ton SH, Palanisamy UD (2015) Perspectives on geraniin, a multifunctional natural bioactive compound. Trends Food Sci Technol 44:243-257. https://doi.org/10.1016/j.tifs.2015.04.010

R Core Team (2017) R: a language and environment for statistical computing [online]. R Foundation for Statistical Computing, Vienna, Austria. Available fromhttp://www.R-project.org/

Rathnayaka RMUSK, Rakshit SK (2009) Comparison of fluorescent in situ hybridization and three specific culture media in enumeration of viable Salmonella enterica from inoculated chicken samples. Proceedings of the international Conference on Innovations in Food Processing Technology and Engineering (ICFPTE'08), Asian Institute of Technology, Pathumthani, Thailand, 19-20 January 2009. Available from https://www.researchgate.net/profile/Udaya _Rathnayaka/publication/233928230_Comparison_of_Fluorescen t_In_SituHybridization_and_Three_Specific_Culture_Media_in Enumeration_of_ViableSalmonella_enterica_from_Inoculated _Chicken_Samples/links/Ofcfd50d13551ee144000000.pdf

Reverón I, Rodríguez H, Campos G, Curiel JA, Ascaso C, Carrascosa AV, Prieto A, de las Rivas B, Muñoz R, de Felipe FL (2013) Tannic acid-dependent modulation of selected Lactobacillus plantarum traits linked to gastrointestinal survival. PLoS ONE 8:e66473. https://doi.org/10.1371/journal.pone.0066473

Rioux D, Blais M, Nadeau-Thibodeau N, Lagacé M, DesRochers P, Klimaszewska K, Bernier L (2018) First extensive microscopic study of butternut defense mechanisms following inoculation with the canker pathogen Ophiognomonia clavigignentijuglandacearum reveals compartmentalization of tissue damage. Phytopathology 108:1237-1252. https://doi.org/10.1094/ PHYTO-03-18-0076-R

Roland JC, Vian B (1991) General preparation and staining of thin sections. In: Hall JL, Hawes C (eds) Electron microscopy of plant cells, Academic Press, London, UK, pp 1-66. 
Rosalam S, England R (2006) Review of xanthan gum production from unmodified starches by Xanthomonas comprestris sp. Enzyme Microb Technol 39:197-207. https://doi.org/10.1016/j. enzmictec.2005.10.019

Rossi F (2011) The challenges of antimicrobial resistance in Brazil. Clin Infect Dis 52:1138-1143. https://doi.org/10.1093/cid/cir120

Roth BL, Poot M, Yue ST, Millard PJ (1997) Bacterial viability and antibiotic susceptibility testing with SYTOX green nucleic acid stain. Appl Environ Microbiol 63:2421-2431. https://doi. org/10.1128/AEM.63.6.2421-2431.1997

Scalbert A (1991) Antimicrobial properties of tannins. Phytochemistry 30:3875-3883. https://doi.org/10.1016/0031-9422(91)83426-L

Scalbert A (1992) Tannins in woods and their contribution to microbial decay prevention. In: Hemingway RW, Laks PE (eds) Plant polyphenols - Synthesis, properties, significance. Plenum Press, New York, USA, pp 935-952

Simionescu N, Simionescu M (1976) Galloylglucoses of low molecular weight as mordant in electron microscopy. I. Procedure, and evidence for mordanting effect. J Cell Biol 70:608-621. https:// doi.org/10.1083/jcb.70.3.608

Trentin DS, Silva DB, Amaral MW, Zimmer KR, Silva MV, Lopes NP, Giordani RB, Macedo AJ (2013) Tannins possessing bacteriostatic effect impair Pseudomonas aeruginosa adhesion and biofilm formation. PLoS ONE 8:e66257.https://doi. org/10.1371/journal.pone.0066257

Ushiki J, Tahara S, Hayakawa Y, Tadano T (1998) Medicinal plants for suppressing soil-borne plant diseases II. Suppressive effect of Geranium pratense L. on common scab of potato and identification of the active compound. Soil Sci Plant Nutr 44:157165. https://doi.org/10.1080/00380768.1998.10414436
Vassallo A, Vaccaro MC, De Tommasi N, Dal Paiz F, Leone A (2013) Identification of the plant compound geraniin as a novel Hsp90 inhibitor. PLoS ONE 8:e74266.https://doi.org/10.1371/ journal.pone.0074266

Volgers C, Savelkoul PHM, Stassen FRM (2018) Gram-negative bacterial membrane vesicle release in response to the hostenvironment: different threats, same trick? Crit Rev Microbiol 44:258-273. https://doi.org/10.1080/1040841X.2017.1353949

Wiegand I, Hilpert K, Hancock REW (2008) Agar and broth dilution methods to determine the minimal inhibitory concentration (MIC) of antimicrobial substances. Nat Protoc 3:163-175. https://doi. org/10.1038/nprot.2007.521

Xu Y, Shi C, Wu Q, Zheng Z, Liu P, Li G, Peng X, Xia X (2017) Antimicrobial activity of punicalagin against Staphylococcus aureus and its effect on biofilm formation. Foodborne Pathog Dis 14:282-287. https://doi.org/10.1089/fpd.2016.2226

Yaganza E-S, Rioux D, Simard M, Arul J, Tweddell RJ (2004) Ultrastructural alterations of Erwinia carotovora subsp. atroseptica caused by treatment with aluminium chloride and sodium metabisulfite. Appl Environ Microbiol 70:6800-6808. https://doi.org/10.1128/AEM.70.11.6800-6808.2004

Youn K, Jun M (2013) In vitro BACE1 inhibitory activity of geraniin and corilagin from Geranium thunbergii. Planta Med 79:10381042. https://doi.org/10.1055/s-0032-1328769

Yount NY, Yeaman MR (2013) Peptide antimicrobials: cell wall as a bacterial target. Ann NY Acad Sci 1277:127-138. https://doi. org/10.1111/nyas. 12005

Publisher's Note Springer Nature remains neutral with regard to jurisdictional claims in published maps and institutional affiliations. 